\title{
Exploring vs. Exploiting Advantages in Industrial Districts
}

\author{
F. Xavier Molina-Morales, M. Ángel López-Navarro, and \\ Jaume Guia Julve*
}

\begin{abstract}
This paper proposes a theoretical integration of social capital and territorial perspectives for the study of industrial districts. Industrial districts benefit from fine-grained information and tacit knowledge exchanges and from norms and values that promote cooperation. These characteristics benefit individual firms for the exploitation, rather than exploration, of technologies and opportunities. We suggest that proximity facilitates the creation of third-party relationships, such as those between firms and regional institutions. These institutions provide individual firms with indirect links to sources of knowledge from outside the district. In order to give support to our theoretical argument we examine the Spanish ceramic tile industrial district and focus on the role played by the Institute of Ceramic Technology as an illustrative case.
\end{abstract}

\section{INTRODUCTION}

Recently, two different interorganizational approaches have been recognized as relevant for the analysis of the value creation and the competitive advantage of the firm. The first is the social capital approach, where social networks provide firms with a set of embedded resources in the form of access channels to knowledge inputs (Burt 1992, 1997) and in the form of norms and values associated with social relationships (Coleman 1990; Portes and Sensenbrenner 1993). The second is the territorial perspective, which has received renewed attention from diverse disciplines. In this field, authors have emphasized the benefits from externalities or nontraded interdependencies to firms in territorially bounded agglomerations (Storper 1992).

By integrating both perspectives, the paper's primary research question investigates the impact of territorial agglomerations, and industrial districts in particular, on social capital. We aim to gain a better understanding of the opportunities and restraints produced by geographical proximity on social networks. First, we describe the basic propositions of the social capital theory, discussing contradictory literature and its implications for industrial districts. This paper states that industrial districts can be defined as networks of dense and strong ties. According to this characterization, industrial districts are much better at exploiting existent opportunities and technologies than exploring new ones. However, our theoretical discussion suggests that local institutions and other local actors in the district can act as intermediary agents that play an important role in providing

\footnotetext{
*Molina-Morales and López-Navarro are from the Department of Business Administration \& Marketing, Universitat Jaume I, Campus Riu Sec, Castellón, Spain, and Julve is from the Department of Business Organization, Universitat de Girona, Sant Feliu de Guíxols, Spain.
} 
the district with new information and knowledge and, thus, in benefiting firms with the informational advantages associated with sparse networks strewn with structural holes.

The paper is structured as follows. First, we briefly review fundamental concepts of the social capital literature, emphasizing the debate on mechanisms and outcomes of the social networks. Then we present a basic description of the concept of industrial districts, focusing on their characterization as a social network and, by presenting opportunities and restraints of this model, we discuss how firms can take advantage of these opportunities while simultaneously reducing the impact caused by the restraints. Finally, the Spanish ceramic tile industrial district is given as an illustrative example to back up our theoretical argument, with special attention given to the role played by the Institute of Ceramic Technology.

\section{SOCIAL CAPITAL}

Social theorists have presented two different dimensions of social capital, known as the structural and relational dimensions. Social capital presents a structural dimension, which refers to social interactions. Authors discuss two different mechanisms and outcomes associated with this dimension. The traditional perspectives of social capital (Coleman 1988, 1990) stressed the positive effect of cohesive networks on the production of social norms and sanctions that facilitate trust and cooperative exchanges. On the contrary, the structural holes approach (Burt 1992, 1997) proposes an alternative perspective that emphasizes the benefits derived from access to diverse information and from brokerage opportunities related to the maintenance of nonredundant relationships.

Secondly, regarding the relational dimension, authors also distinguish between two different mechanisms and outcomes according to the strength of the ties. On one hand, strong ties provide the organizations with two primary advantages. Strong ties are associated with exchanges of high-quality information and tacit knowledge (Uzzi 1996) and serve as a mechanism of social control that governs the interdependencies in partnerships. On the other hand, Granovetter (1973) argues that weak ties allow an actor to access new information. However, it has been proved that the informational benefits derived from weak ties have less to do with the intensity of the ties and more to do with the structural holes that are normally associated with them, from which firms gain access to nonredundant sources of information (Krackhardt 1992).

In this context, social capital theorists agree in considering that the "best connected" actors in their networks possess an advantage with respect to those who are poorly connected. However, disagreement exists when it comes to defining "best connected." According to Coleman (1988) or Uzzi (1997), arguments surrounding the role of networks of close and strong ties suggest the supremacy of the closure approach. In contrast, Burt (1992) and Granovetter (1973) claim that firms should be connected in disperse networks with mutually disconnected partners. 
Recently, authors have attempted to conciliate these contradictory perspectives. Rowley, Behrens, and Krackhardt (2000) stated that both perspectives are useful in explaining benefits for different strategic purposes. ${ }^{1}$ According to these authors, a number of conditions can be established under which firms are better connected in each type of network. One of the main elements that defines the advantages provided by each type of network for the firms is the extent to which their strategies are aimed at exploring emergent innovations and other significant changes in the environment or, on the contrary, are aimed at exploiting existent technologies, capabilities, and information. This argument was supported by Dyer and Nobeoka (2000), who reported the case of the Toyota suppliers network as an example of a dense and strong tie network that has been designed to exploit opportunities rather than to explore new ones.

Podolny and Baron (1997) suggested that the benefits of a network structure are contingent on the nature of the interdependence among participants. Networks rich in structural holes may provide valuable information about new opportunities, but cohesive ties among participants are cooperative links required for the actors to exploit these opportunities and, thus, they are also an essential component of success. In addition, Gargiulo and Banassi (2000) presented a tradeoff between safety in cooperation within cohesive networks and flexibility within networks rich in structural holes.

Consequently, the type of social capital required by firms must be influenced by divergent requirements for information. Two different types of requirements can be identified according to whether the purpose of the relation is to explore or to exploit. In the case of exploration, firms are focusing on obtaining new information from many different alternative sources. Here, information is relatively broad and general in nature, due to the fact that emphasis is put on the identification of viable alternatives rather than on a complete understanding of how each innovation must be developed. Concerning exploitation, the emphasis is on refining an existent innovation in order to gain in efficiency within a particular area. Therefore, in an evolutionary context, firms should have a mix of both types of ties (Rowley, Behrens, and Krackhardt 2000).

Thus, particular types of social networks may provide firms with both exploiting and exploring advantages. According to the conditions of the environment, firms must decide on which network strategy they should favor.

\section{TERRITORIAL PERSPECTIVES}

The amount of attention given to the concept of the industrial district, i.e., the territorial agglomeration of firms, has been growing steadily in economics literature over the last two decades, probably due to the success observed in economic activities that are geographically concentrated. This interest has given rise to a great number of contributions by scholars from a wide range of disciplines, including geography (Krugman 1991; Lundvall 1992); political economy (Piore

${ }^{1}$ In a more recent piece of work, Burt (1998) agreed that dense network and structural hole arguments are not at all contradictory, but serve different objectives. 
and Sabel 1984; Best 1990; Digiovanna 1996; Mistri 1999); sociology (Saxenian 1994; Lazerson 1995), and strategy (Porter 1990; Enright 1995). As a result, we are confronted with a great variety of concepts to explain this phenomenon. As Storper and Harrison (1991) pointed out, the sheer number of concepts and approaches, such as flexible specialization (Piore and Sabel 1984), production system (Storper and Harrison 1991), regional cluster (Porter 1990; Enright 1995), national system of innovation (Lundvall 1992), or hot spot (Pouder and John 1996), often produces confusion and makes understanding the phenomenon more difficult.

Yet, while the extended relationships that develop under circumstances of physical proximity may vary considerably in their details, their underlying logic is constant. Industrial districts in southwestern Germany or northern central Italy are based on a set of local circumstances, but the principles of mutual organization on which these districts are based are more widely applicable. Similar interfirm cooperation is often found in economic activities based in a particular region (e.g., Scandinavia) or in areas where firms from similar industries are spatially concentrated, such as the Silicon Valley in the United States. And case studies prove it to be a worldwide phenomenon that is found in Japan (Friedman 1988), the United States (Scott 1991; Maarten de Vet and Scott 1992; Saxenian 1994), Germany (Herrigel 1996), Denmark (Kristensen 1992), Brazil (Schmitz 1995), Mexico (Rabellotti 1995), India (Cawthorne 1995), and Italy (Pyke and Sengenberger 1992).

But what exactly do we mean by "industrial district?" In an introductory work, Pyke and Sengenberger (1992, p. 4) describe the main characteristic of the industrial district as the existence of strong networks of (chiefly) small firms. Through specialization and subcontracting they share out amongst themselves the labor required for the manufacture of particular goods-specialization induces efficiency, and specialization combined with subcontracting promotes collective capability. Moreover, industrial districts promote trust and cooperation, which shows entrepreneurial dynamism and flexibility. In this paper, we use the term "industrial district" as defined by Becattini (1990, p. 39), namely, "A sociogeographical entity which is characterized by the active presence of both a community of people and a population of firms in one naturally and historically bounded area." Thus, we may say that an industrial district is comprised of numerous small firms engaged in related interdependent activities that are located within a clearly identifiable community. This "togetherness" implies a cultural homogeneity that gives rise to an atmosphere of cooperative and trusting behavior in which economic action is regulated by implicit and explicit rules (Lazerson and Lorenzoni 1999).

So what are the advantages of industrial districts? Marshallian, or agglomeration, economies were the first justification for the benefits that the industrial district offered to firms. The author of the original concept of industrial district, Marshall (1925), identified a class of external economies that focus on the benefits gained by individual firms or plants from the increased pooling of common factors 
like skilled human resources, specialized suppliers, and technological spillovers (Krugman 1991). Likewise, the Marshallian concept of industrial atmosphere can be defined as the existence of some intangible resources based on experience, knowledge, and information that are common to district firms.

In general, authors now argue that geographical agglomerations benefit firms in the form of positive externalities or nontradable interdependencies (Storper 1992). Some of them emphasize the superiority of this form of industrial organization over mass production and vertically integrated companies (Piore and Sabel 1984; Best 1990). Like Crewe (1996), Russo (1997), and Paniccia (1998), Harrison (1992) pointed out that the most important implication of industrial districts goes beyond the agglomeration economies and refers to the presence of a community of people. Through a shared knowledge base and continual contracting and re-contracting, experience fosters relational trust and this relational trust, in turn, limits opportunism among partners in this communitarian industrial district market (Lorenz 1992; Dei Ottati 1994; Foss and Koch 1995; Lazerson 1995). Indeed, relational trust is fundamental in explaining the most important net result of this embedding-the paradoxical combination of cooperation and competition in the industrial district (Harrison 1992).

\section{THE INDUSTRIAL DISTRICT AS A SOCIAL NETWORK}

As Piore (1990) has reported, the term "network" has frequently been used to characterize the relationships among productive units in the district. In this way, it is easier to understand the contrast between the type of internal communication that takes place within the industrial district and the authority line and type of communication dominant in the large, vertically integrated firm. The predominance of resources associated with social networks has been covered increasingly in the regional literature. It is argued that knowledge, social capital, and institutions are concepts that may be more important than the traditional consideration of economic development (Malecki 2000). Moreover, Hansen (1990, 1992) reports some French experiences supporting the idea that noneconomic factors can better explain why some regions are successful and others fail in their development strategies. Externally planned heavy industrial complexes as scientific technopoles (i.e., Sophia Antipolis) have relatively little impact in terms of diffusing development on a regional basis. In contrast, this last author reported successful experiences, such as Marseille or Montpellier, that include social, cultural, and environmental factors as well as a decentralized network.

The network metaphor has been used to define relationships among organizations in an industrial district where firms with shared goals have territorial proximity as an additional defining element. Moreover, the usage of concepts such as embeddedness and social capital has spread rapidly in the territorial literature, primarily as a consequence of the inherently spatial character of the term embeddedness (Oinas 1998). Despite the presence of long-distance interaction, most contacts, especially of an informal nature, are within a short radius of one's home base (Malecki 1995). 
Industrial district theorists have often argued over the two different kinds of benefits that firms can gain from their social relationships, that is, the norms and values present in the industrial district, and the information and tacit knowledge transmission flows that take place there.

\section{Norms and Values in the Industrial Districts}

Norms and values in territorial agglomerations have usually been discussed in the industrial district literature. Cultural homogeneity produces an atmosphere of cooperative and trusting behavior in which economic action is regulated by implicit and explicit rules (Lazerson and Lorenzoni 1999). Within the districts, a set of assets is collectively generated that takes the form of shared norms and values. Relational and individual trust emerge with reinforcement mechanisms, such as reciprocity, experience, repeated relationships, and a longterm perspective. Parallel to this, protection or safeguard mechanisms, such as restrictive access, reputation, or collective penalties, are also developed.

Lorenz (1992) emphasized the emergence of informal ties in territorial agglomerations that go beyond and are deeper than mere formal contracts. This author has collected an emotive vocabulary, frequently used by managers and entrepreneurs, including such words as collaboration, loyalty, morality, and mutual trust. The transcendence of the informal ties is in consonance with the active role that Granovetter (1985) concedes to concrete personal relationships.

If trust can be better built through learning from the idiosyncrasies of interdependent actors and if that requires repetitive interactions, then these interactions are likely to be facilitated by personal contacts, which are more probable and intense with geographical proximity. To sum up, the simple logic is that proximity leads to mutual experience, which, in turn, leads to trust and collaboration and finally to the improvement of economic development (Harrison 1992).

In addition to the presence of these assets in the dyadic relationships or in the firm's particular networks, the whole district is identified as a community of people. This community extends the embedded assets derived from the network of social relationships to all the participants throughout the whole system. The sense of belonging is defined as the criterion that brings the community together and gives it an identity. Trust is based on a shared sense of community with a common purpose and goal. In other words, trust and trustworthiness become membership conditions (Becattini 1979).

\section{Information and Tacit Knowledge Transmission Mechanisms}

The intensity of the relationships and the existence of informal relations (mostly based on nonbusiness ties) produce fine-grained information and tacit knowledge transmission. In the industrial district literature, authors have discussed three different transmission mechanisms: nonbusiness relations, new firms, and human resources mobility.

Brusco (1990) pointed out that in order to understand the capacity of invention in the industrial districts it is essential that many people understand the 
technology they work with. These requirements require continuous interactions outside the workplace, i.e., in social and kinship events and relations. In this way, new ideas are continuously transmitted.

New firms constitute the second mechanism. They are mainly created by managers and employees from a parent firm and are normally located in the areas where the founders have lived and worked (Bramanti and Senn 1990). As Johannisson and Monsted (1997) pointed out, intersectorial trust and informal social capital are accumulated in districts due to the close interconnections between business and community, thus creating an incubative arena for entrepreneurial activity. The founders of new firms accumulated a great amount of experience and specific knowledge from their previous jobs. This context-specific knowledge has to do with the products and technologies present in the district.

Human resources mobility is another knowledge transmission mechanism. If employees leave a firm, they carry with them their tacit knowledge and enrich the local human resource market (Tomlinson 1999). Obviously, tacit knowledge depends on previous experience and is therefore related to one particular industry or technology. For knowledge to actually flow across firms' boundaries, both a certain degree of human resource immobility as regards the external boundaries of the district and a certain degree of internal district mobility are both required (Brenner 2000).

\section{Exploration Versus Exploitation Purposes and the Local Institutions}

What kind of social network is an industrial district? According to industrial district theorists, it can be seen as a cohesive, dense, and strong-tie network of contacts. Consequently, firms benefit from efficiency in exploiting existing opportunities through the sharing of high-quality information, tacit knowledge, and cooperative exchange.

In contrast, firms may have problems accessing new and unique information and may only obtain limited benefits related to the diversity of information accessible, and to the brokerage opportunities stemming, from networks with nonredundant ties. Supporting this conclusion, Glasmeier (1991), in terms similar to Harrison (1994), described how the Swiss watch firms showed themselves to be vulnerable when responding to radical external technological changes, that is to say, they had exploring disadvantages. Similarly, Lazerson and Lorenzoni (1999) reported some cases in the Mafia regions where cultural homogeneity generates disadvantages for firms.

In spite of these arguments emphasizing the limitations of the industrial district in accessing new opportunities, there are many other cases that prove that industrial districts benefit firms by providing both exploiting and exploring advantages (for instance, the Silicon Valley or Third Italy). Saxenian (1991) found that in the rapidly changing environment of the computer industry, especially in the Silicon Valley, firms have moved away from arm's-length supplier relations in order to build close relationships with only a selected number of them. 
Following from Granovetter (1973), Grabher (1993) refers to the risk of "lock-in" and group thinking, particularly when the district has to face radical external technological changes. This problem is an expression of the limitation of the dense and strong ties that characterize the districts. In fact, firms in industrial districts must search for new opportunities to improve and renew their capabilities, especially those that are associated with innovation. However, the exploring activities (searching for information and opportunities) imply a high level of uncertainty and risk with respect to value and the extent to which they benefit the firm. Firms in industrial districts face problems of search costs in scanning and analyzing new information and opportunities. Consequently, firms can take advantage of having networks of ties with local institutions that provide a feasible source of information about the options for enhancing firms' capabilities. This implies a high propensity for experimentation, monitoring, information processing, and knowledge extraction and, on the other hand, requires network management of the kind described in Cooke and Morgan (1998). Some examples of this can be found in the Netherlands, Germany, or Wales with the idea of "innovation assistant" (Cooke 2002).

How can firms redundantly connected with other participants in an industrial district have access to new and external information and opportunities at the same time? We suggest that regional intermediaries, in particular regional institutions, can prevent the disadvantages derived from the absence of nonredundant ties for the individual firms. The existence of local institutions in industrial districts has been widely discussed in the literature. Indeed, the industrial district has been viewed as a field of political action. Although a great variety of arrangements exists, in general, in the industrial district, there is a set of both private and public institutions that develop activities that support the whole district. They include a range of institutions: universities, research and other academic institutions, regional industrial policy agents, or trade and professional associations. An inventory of experiences can be found in Cooke and Morgan (1998), Cooke $(1999,2002)$, and Morgan (1999), where the authors reported different cases of European regional development. These studies included both leading European regions (Emilia-Romagna and Baden-Württemberg) as well as less-favored regions (including the Valencian Community in Spain). The European experiences say that there should be an unwritten social constitution that encourages firms, their associations, and local public institutions to pursue and accomplish their interests through joint solutions to common problems. As a result, the districts avoid the cutthroat form of competition. The state has a positive role to play in promoting innovation, especially with regard to small and medium enterprises (SMEs), technology transfer, education, and training. Success depends on how all key institutions orchestrate their efforts, how well they collaborate to achieve mutually beneficial ends-in short, how well they function as a "collective entrepreneur," spreading the costs and the benefits of technical innovation and social adjustment throughout the region (Morgan 1999). 
Local institutions facilitate managerial innovation by providing access to information and resources, which in turn enable firms to acquire new, and extend existing, innovation capabilities (McEvily and Zaheer 1999). Local institutions also reduce search costs associated with locating external sources of the knowledge and specialized expertise that is critical for the district firms. By maintaining an extensive network of ties, local institutions generate search economies. Individual firms in the industrial district can employ a substantial part of their time in developing other activities (Galaskiewicz 1985).

\section{ILLUSTRATIVE EXAMPLE}

So far, we have suggested that regional intermediaries, in particular regional institutions, can help the individual firms in their networks to avoid the disadvantages associated with the absence of nonredundant ties. Regional intermediaries provide firms with access to information and resources. In this way, firms in the industrial district can combine the advantages of both exploiting existing technologies and exploring new opportunities.

To illustrate this argument we have analyzed the Spanish ceramic tile industry and have focused on the role played by the Institute of Ceramic Technology (ITC) as one of the most important regional institutions in the district. As a further source of data in addition to surveys and publications, we carried out a number of semi-structured interviews with managers of the local institutions. The criteria used for the selection of the institutions were based on the relative importance and accessibility of the institutions. Although the interviews generally provided us with interesting information and feedback, without a doubt the institution that stands out most-both for its influence on the district development and for our paper-was the ITC. Apart from long talks with a number of colleagues from the University, we also carried out interviews with the following institutions: the ITC, the Spanish Association of Ceramic Tile Manufacturers (ASCER), the Association for Ceramic Promotion and Design, Fundació Universitat Jaume IEmpresa, the Spanish Association of Frit and Glaze Manufacturers, and the Spanish Association of Ceramic Machinery and Equipment Manufacturers.

\section{The Spanish Ceramic Tile Industrial District}

Within the Spanish ceramic tile industry, an industrial district has been identified in Castellón. This district has specialized in the production of ceramic floor and wall tiles. Its most relevant characteristics are high geographical concentration ( 90 percent of total Spanish production is located inside the district boundaries within a 20-kilometer radius of the city of Castellón), and high internal rivalry (no individual firm is responsible for more than 3 percent of total output). Economic performance shows continuous growth (19 percent annual average sales growth for this decade), a high export activity rate (56 percent in 1998), and a progressive reduction of the gap in relation to the other world leader, Sassuolo (Italy). Likewise, in 1998, the Spanish international market share was 30 percent, thus surpassing the Italian cluster in terms of production. 
A number of authors have previously identified the Castellón area as an industrial district (Utili, Sarti, and Gobbo 1983; Castillo 1989; Benton 1992; Nomisma 1992; Ybarra 1991; Costa 1993). In particular, Ybarra (1991) used Sfrozi's method based on above-average density of specialized SMEs in a bounded geographical area. Moreover, most authors include the Spanish case within the Italian model on the basis of similarities in origin and evolution with respect to the Italian ceramic tile district. Similarities in origin and evolution between Spanish and Italian ceramic tile districts enabled us to take Russo (1985) as a starting point, particularly with regard to her emphasis on economic, social, and institutional features in the creation and diffusion of the innovations.

\section{The Industrial District as a Network of Dense and Strong Ties}

We found a number of traditional traits in this particular district that helped us to draw up a profile of the strong social context in which firms in the district operate. These included the proximity of human resources to the firms, the relevance of the ceramic activity in the area, and the opportunity for particular firms to reach interfirm agreements.

Previous studies have already pointed out that the district employees' home distance from the firm is relevant (Costa 1993). In fact, 60 percent of the employees live in the same town and 38 percent live in other areas within the district. Therefore, if informal relationships require geographical proximity, we can infer that proximity facilitates frequency of contact and extrabusiness interrelations.

Moreover, taking the city of Castellón as the epicenter of the district, the average distance between firms is 16.34 kilometers, and when we also include the firms operating in auxiliary and related activities, the average distance drops to 9.1 kilometers. The geographical distribution of the companies is concentrated around four local centers with the same relative importance, and thus this geographical distribution of both people and firms produces important overlaps between business and social relationships. Geographical distance among actors in the networks is an indicator of the frequency and nature of contacts (McEvily and Zaheer 1999). The proximity between firms and institutions in the studied district (less than 20 kilometers) allowed daily, face-to-face contacts. This proximity is particularly important in the transmission of tacit knowledge.

Another indicator of embeddedness refers to what we call the social relevance of the ceramic activity. We observe that in areas where district activities are predominant, a good part of social life runs around them. ${ }^{2}$ In towns where ceramic activity accounts for 80 or 90 percent of the economic activity, "industry is in the air." Even people with jobs in economic activities unrelated to ceramic tile production are aware of production and market news and innovations. The high percentage of companies and employees directly related to the activities of the district (ceramic tile production) out of the total in each of the four local areas tells us

${ }^{2}$ According to the ARDAN database, ceramic activities in terms of number of firms and number of employees are dominant in the area. When Castellon, as the administrative capital, is included, ceramic activities account for 50.3 percent of total firms and 67.5 percent of total employees, while, when the capital is not included, they account for 78.6 percent of total firms and 85.6 percent of total employees. 
about the overlaps between social and business relationships in these areas. We mean that, if a specific economic activity is predominant to such a high degree in a certain localized area, then most of the social life of the people would take place around this activity, unlike what could be expected to happen in other more economically diversified areas.

In addition, the mechanisms used for the transmission of knowledge within the district are, basically, (1) nonbusiness or kinship relationships; (2) newly created firms; and (3) human resources moving within the district.

Initially, we investigated firm age by looking at companies from the 1960s onwards. When we considered companies that still exist, the average age was 24 years. The number of firms founded in each period was stable over the periods. Later, we collected the number of firms that died during the period from 1985 to 2000 , which came to 44 in all. In contrast, the number of new foundings totaled 114. Taking the number of remaining firms as a base, these data give us a 29.5 percent death rate and a 76.5 percent birth rate, which together imply high vitality in the district (ASCER 2000). In particular, the rate of new firm creation is relevant in the context of knowledge transmission, since in most of the cases the founders of new firms are former managers or employees from other district firms.

Most of the managers, technicians and, in general, employees in firms have had previous experience with other firms in the same district, and so firms fear losing employees as a result of internal district mobility. Kinship and social relationships based on proximity facilitate informal contact and information transmission through strong informal channels of communication.

We also found from our survey results that firms do not consider the knowledge of their employees to be exclusive or specific at the firm level. Instead, they consider this knowledge to be similar to knowledge in other firms within the district but different from the knowledge found in firms outside it. On the basis of these findings, we can assume that there is specific employee knowledge at the district level rather than at the individual firm level. Employees can move from firm to firm within the district without losing significant value of their knowledge. A significant loss of the value of that knowledge only occurs when they move outside the district (district-bound appropriable quasi-rents). Consequently, there is a high internal mobility of employees and limited mobility to firms outside the district.

\section{The Local Institutions in the Ceramic Tile District}

In the Spanish ceramic tile district, we find a set of local institutions providing support and services to the entire district network. They are both public and private institutions: academic institutions, trade and professional associations, and regional industrial policy agencies (Table 1). These institutions carry out $\mathrm{R} \& \mathrm{D}$ activities, specific training, product promotion, etc. 


\section{TABLE 1}

Ceramic Industrial District Institutions

\begin{tabular}{l} 
INSTITUTION \\
\hline Universitat Jaume I (UJI) \\
Institute of Ceramic Technology (ITC) \\
Association for Ceramic Promotion and \\
Design (ALICER) \\
Association of Ceramic Technicians (ATC)
\end{tabular}

University - Companies Foundation ACTIVITIES

Higher training and research

Research and development technological institute

Ceramic design

Ceramic technological publishing, meetings and congresses

Institute of Ceramic Promotion

Relations between Universitat Jaume I and companies

Castellón School of Arts and Crafts

Documentation center

Ceramic design

Institute of Vocational Training of Caminas Technology

Trade Associations

ASCER: Association of Ceramic Tile Manufacturers of Spain; ANNFFEC: Association of Frit and Glaze Manufacturers of Spain; ASEBEC: Association of Ceramic Machinery and Equipment Manufacturers of Spain

CEVISAMA International Ceramic Show

Annual sector trade fair

QUALICER, Tile Quality World Conference Biannual conference

Public Institutions (Chamber of Commerce, Industrial policy

Regional Government, etc.)

Azulejo, Tecnica Ceramica, and others

Periodical publications

Among these institutions, we have chosen to analyze the ITC. Our interest in this particular institution lies in its importance in supplying information and knowledge flows within the district.

\section{The Institute of Ceramic Technology}

What is the ITC? The ITC is a research institute integrated in Castellón's Universitat Jaume I, and is associated with the Association for Research in the Ceramic Industries. The chief participants in the ITC are the local University, ceramic firms through ASCER, and the regional government through IMPIVA (a regional industrial policy agency).

What does the ITC do? In short, the ITC carries out the following activities: (1) Technological Transfer. Applying and adapting technologies developed in other industrial sectors to the ceramic sector; (2) RED. Development of new components and new compositions and optimization of the ceramic processes; (3) Technological Services. Standardization of raw materials, controls of production systems, installation of quality and environmental control systems; and (4) Training. Specific courses, periodical publications, and participation in congresses and conferences. 


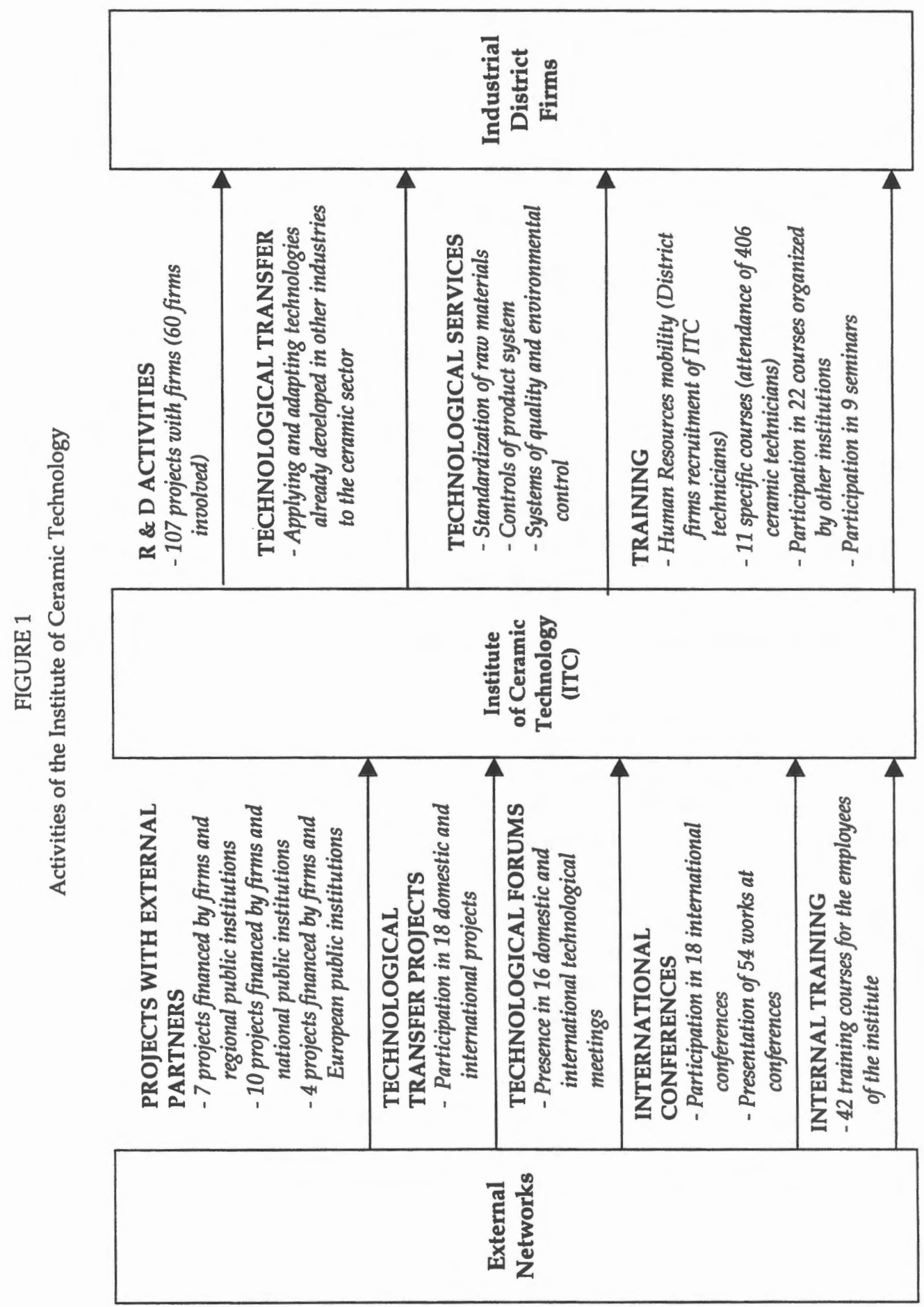


How does the ITC play the role of intermediary within the district network? Figure 1 shows the role of the ITC as an intermediary agent for the district firms (data correspond to the year 1999). On the left, the ITC is linked to several external unconnected networks. Therefore, the ITC may attain brokerage advantage through structural holes in its particular network. As a result of that, the ITC can explore emerging innovations and other significant external changes. On the right of the figure, firms within the district establish a dense strong-tie network with each other. The ITC provides the district with new technology, external innovation, or opportunity, and then firms exploit them efficiently taking advantage of their dense network. In this way, from the individual firm's point of view, the district provides the firms with an optimal portfolio of indirect ties, which support both their exploration and exploitation requirements.

External Networks. The ITC develops contacts with external networks from which it explores innovations and new opportunities generated in other related sectors and then carries out the corresponding transfer of technology. We have identified a number mechanisms used in the exploration of new opportunities. First, the ITC research institute participates in a number of research projects with external partners. These research programs are financed by firms and regional, national, and European governments. In addition, the ITC participates in a total of 18 technological transfer projects. Secondly, the ITC actively participates in technological forums, international conferences, and academic activities (i.e., scientific meetings and conferences, and publishes its work in scientific reviews, books, and doctoral theses). The ITC also provides training for its employees by developing internal training programs.

Internal District Networks. First, the ITC is a partner in R\&D projects with district firms. During 1998 and 1999, the ITC carried out 107 research projects with 60 ceramic tile firms. R\&D activities in the institute are focused on both improvements in the production process and improvements in product characteristics, as well as the development of new products. Secondly, technological services accounted for more than 250 analyses and tests conducted over the period 1998-1999. These services included information and documentation on quality systems. Finally, other ITC activities are related to training staff in firms, and promotion of the ceramic tile industry in the market.

\section{CONCLUSIONS}

The primary research objective of this paper has been to investigate how geographical proximity affects firms' social networks. By integrating both social capital and territorial theoretical perspectives we conclude that a territorial agglomeration-i.e., industrial district-can be considered a network of dense and strong ties. Hence, firms can benefit from exploitation strategies rather than from exploration of new opportunities. However, we argue that local institutions, acting as intermediary agents, can provide firms with new information collected through their external networks, which are rich in structural holes. 
The brief description of the Spanish ceramic tile industry illustrates how firms in the industrial district can effectively pursue both exploitation and exploration purposes. On the one hand, the ITC and other local institutions that act as intermediaries provide new information about technologies and opportunities that are available through their external networks. These networks are rich in structural holes and thus the disadvantages of redundancy are prevented from occurring. The ties of individual firms in the district with these institutions produce benefits similar to those provided by direct ties with contacts outside the district. Hence, individual firms can see their search costs reduced while at the same time receiving diverse and valuable information. Once new information is in the district, the dense internal network facilitates the spreading of this information among the firms, as well as the improvement of existing capabilities and opportunities.

We argue that firms should develop a distinct capacity. This capacity refers to the creation and leverage of the shared strategic local resources. Firms should interact with local institutions and other district participants in order to improve environmental conditions. Dynamics between the formation of tacit and codified knowledge call for a reassessment of institutional arrangements. Firms should develop close links with local institutions. Social networks facilitate the rapid transmission of evolving uncodified knowledge. Firms may pursue diverse strategies for knowledge and skills resourcing. These may include, among others, strategic partnerships with key institutions to influence the education and training of future researchers; research collaboration with individual academics or departments in universities in order to gain early access to research; or, finally, the creation of hybrid research organizations of firms and institutions to develop common research programs. This suggestion is in line with Maskell et al. (1998). According to these authors, firms located in areas where the localized capabilities are particularly fitted to satisfy their needs will have higher survival and growth rates than similar firms located elsewhere. Localized capabilities may also deteriorate over time, and this may undermine the competitiveness of firms located there. Mechanisms through which this may happen have one effect in common, they imply that in regions and countries, just like in firms, there is a need for "unlearning," and the process of un-learning will often necessitate the disintegration and removal of formerly important institutions and built structures that may act as hindrances to further development.

This study could be extended in various directions. For example, it could be useful to undertake comparative work within districts across different sectors and countries. This should not be restricted to aggregated quantitative data but also involve data of an in-depth qualitative nature to explain behavioral differences between firms and districts. 


\section{REFERENCES}

ASCER. Annual Report, 2000. Castellón: Publicasa, 2000.

Becattini, G. "The Marshallian Industrial District as a Socio-Economic Notion." In F. Pyke, G. Becattini, and W. Sengenberger (eds.) Industrial Districts and Inter-Firm Cooperation in Italy. Geneva: International Institute for Labor Studies, 1990.

. "Dal Settore Industriale al Distretto Industriale. Alcune Considerazioni sull'unità di Indagine in Economia Industriale." Revista di Economia e Politica Industriale 1 (1979), 7-14.

Benton, L. "The Emergence of the Industrial District in Spain." In F. Pyke and W. Sengenberger (eds.) Industrial Districts and Local Economic Regeneration. Geneva: International Institute for Labor Studies, 1992.

Best, M. The New Competition: Institutions of Industrial Restructuring. Cambridge, Mass.: Harvard University Press, 1990.

Bramanti, A., and L. Senn. "Product Innovation and Strategic Patterns of Firms in a Diversified Local Economy: The Case of Bergamo." Entrepreneurship $\mathcal{E}$ Regional Development 2 (1990), 153-180.

Brenner, T. "Industrial Districts: A Typology from an Evolutionary Perspective." Paper for DRUID's Summer 2000 Conference, Rebild, Denmark, June 15-17, 2000.

Brusco, S. "The Idea of the Industrial District. Its Genesis." In F. Pyke, G. Becattini, and W. Sengenberger (eds.) Industrial Districts and Inter-Firm Cooperation in Italy. Geneva: International Institute for Labor Studies, 1990.

Burt, R.S. "Social Structure of Competition." In N. Nohria and R.G. Eccles (eds.) Networks and Organizations: Structure, Form and Action. Boston: Harvard Business School Press, 1992.

. "The Contingent Value of Social Capital." Administrative Science Quarterly 42 (1997), 339-365.

"The Network Structure of Social Capital." Presentation for the Social Networks and Social Capital Conference, Duke University, Durham, N.C., October 30-November 1, 1998.

Castillo, J.J. "El Distrito Industrial de la Cerámica de Castellón." Revista de Treball 11 (1989), 93-104.

Cawthorne, P. "Of Networks and Markets: The Rise and Rise of a South Indian Town, the Example of Tiruppur's Cotton Knitwear Industry." World Development 23 (1995), 43-56.

Coleman, J.S. "Social Capital in the Creation of Human Capital." American Journal of Sociology 94 (1988), 95-120.

. Foundation of Social Theory. Cambridge, Mass.: Harvard University Press, 1990.

Cooke, P. "The Co-operative Advantage of Regions." In T.J. Barnes and M.S. Gertler (eds.) The New Industrial Geography. London: Routledge, 1999. 
. Knowledge Economies: Clusters, Learning and Cooperative Advantage. London: Routledge, 2002.

Cooke, P., and K. Morgan. The Associational Economy: Firms, Regions, and Innovation. Oxford: Oxford University Press, 1998.

Costa, M.T. EXCEL. Cooperación entre Empresas y Sistemas Productivos Locales. Madrid: IMPI, 1993.

Crewe, L. "Material Culture: Embedded Firms, Organizational Networks and Local Economic Development of a Fashion Quarter." Regional Studies 30 (1996), 257-272.

Dei Ottati, G. "Co-operation and Competition in the Industrial District as an Organizational Model." European Planning Studies 2 (1994), 463-485.

Digiovanna, S. "Industrial Districts and Regional Economic Development: A Regulatory Approach." Regional Studies 30 (1996), 373-386.

Dyer, J.H., and K. Nobeoka. "Creating and Managing a High Performance Knowledge Sharing Network: The Case of Toyota." Strategic Management Journal 21 (Special Issue) (2000), 345-367.

Enright, M.J. “Organization and Coordination in Geographically Concentrated Industries." In N. Lamoreaux and D. Raff (eds.) Coordination and Information: Historical Perspectives on the Organization of Enterprise. Chicago: Chicago University Press for the NBER, 1995.

Foss, N.J., and C.A. Koch. "Opportunism, Organizational Economics, and the Network Approach." Scandinavian Journal of Management 12 (1995), 189-205.

Friedman, D. The Misunderstood Miracle. New York: Cornell University Press, 1988. Galaskiewicz, J. Social Organization of an Urban Grants Economy. Orlando: Academic Press, 1985.

Gargiulo, M., and M. Banassi. "Trapped in Your Own Net? Network Cohesion, Structural Holes, and the Adaptation of Social Capital." Organization Science 11 (2000), 183-196.

Glasmeier, A. "Technological Discontinuities and Flexible Production Networks: The Case of Switzerland and the World Watch Industry." Research Policy 20 (1991), 469-485.

Grabher, G. "The Weakness of Strong Ties: The Lock-in of Regional Development in the Ruhr Area." In G. Grabher (ed.) The Embedded Firm: On the Socioeconomics of Industrial Networks. London: Routledge, 1993.

Granovetter, M. "The Strength of Weak Ties." American Journal of Sociology 78 (1973), 1360-1380.

" "Economic Action and Social Structure: The Problem of Embeddedness." American Journal of Sociology 91 (1985), 481-510.

Hansen, N. "Innovative Regional Milieux, Small Firms, and Regional Development: Evidence from Mediterranean France." The Annals of Regional Science 24 (1990), 107-123.

"Competition, Trust and Reciprocity in the Development of Innovative Regional Milieux “ Papers in Regional Science 71 (1992), 95-105. 
130 Molina-Morales,

López-Navarro \& Julve

Harrison, B. "Industrial Districts: Old Wine in New Bottles?" Regional Studies 26 (1992), 469-483.

. Lean and Mean. New York: Basic Books, 1994.

Herrigel, G. Industrial Constructions: The Sources of German Industrial Power. Cambridge: Cambridge University Press, 1996.

Johannisson, B., and M. Monsted. "Contextualizing Entrepreneurial Networking: The Case of Scandinavia." International Studies of Management $\mathcal{E}$ Organization 27 (1997), 109-136.

Krackhardt, D. "The Strength of Strong Ties." In N. Nohria and R.G. Eccles (eds.)

Networks and Organizations: Structure, Form and Action. Boston: Harvard Business School Press, 1992.

Kristensen, P.H. "Industrial District in West Jutland." In F. Pyke and W. Sengenberger (eds.) Industrial Districts and Local Economic Regeneration. Geneva: International Institute for Labor Studies, 1992.

Krugman, P. Geography and Trade. Cambridge, Mass.: MIT Press, 1991.

Lazerson, M. "A New Phoenix? Modern Putting-Out in Modena Knitwear Industry." Administrative Science Quarterly 40 (1995), 34-59.

Lazerson, M.H., and G. Lorenzoni. "The Firms that Feed Industrial Districts: A Return to the Italian Source." Industrial and Corporate Change 8 (1999), 235-266.

Lorenz, E.H. "Trust, Community, and Co-operation. Toward a Theory of Industrial Districts." In M. Storper and A.J. Scott (eds.) Pathways to Industrialization and Regional Development. London: Routledge, 1992.

Lundvall, B.A. National Systems of Innovation. London: Pinter, 1992.

Maarten de Vet, J., and A. Scott. "The Southern Californian Medical Device Industry: Innovation, New Firm Formation, and Location." Research Policy 21 (1992), 145-161.

Malecki, E. "Culture as Mediator of Global and Local Forces." In B. Van der Knaap and R. Le Heron (eds.) Human Resources and Industrial Spaces: A Perspective on Globalization and Localization. Chichester: John Wiley \& Sons, 1995. . "Soft variables in Regional Science." The Review of Regional Studies 30 (2000), 61-69.

Marshall, A. Principles of Economics (1890). 8th ed. London: Macmillan, 1925.

Maskell, P., H. Eskelinen, I. Hannibalsson, A. Malmberg, and E. Vatne. Competitiveness, Localised Learning and Regional Development: Specialisation and Prosperity in Small Open Economies. London: Routledge, 1998.

McEvily, B., and A. Zaheer. "Bridging Ties: A Source of Firm Heterogeneity in Competitive Capabilities." Strategic Management Journal 20 (1999), 1133-1156.

Mistri, M. "Industrial Districts and Local Governance in the Italian Experience." Human Systems Management 18 (1999), 131-139.

Morgan, K. "Reversing Attrition? The Auto Cluster in Baden-Württemberg." In T.J. Barnes and M.S. Gertler (eds.) The New Industrial Geography. London, Routledge, 1999. 
Nomisma. Competitivita e Concorrenza nell'industria delle Piastrelle. I Productori Italiani e Spangoli nell'evoluzione del Settore. Bologna: Laboratorio di Politica Industriale, Assopiastrelle Eds., 1992.

Oinas, P. The Embedded Firm? Prelude for a Revived Geography of Enterprise. Helsinki: Helsinki School of Economics and Business Administration, 1998.

Paniccia, I. "One, a Hundred, Thousands of Industrial Districts. Organizational Variety of Local Networks of Small and Medium-Sized Enterprises." Organizational Studies 19 (1998), 667-699.

Piore, M. "Work, Labor and Action: Work Experience in a System of Flexible Production." In F. Pyke, G. Becattini, and W. Sengenberger (eds.) Industrial Districts and Inter-Firm Cooperation in Italy. Geneva: International Institute for Labor Studies, 1990.

Piore, M., and C. Sabel. The Second Industrial Divide: Possibilities for Prosperity. New York: Basic Books, 1984.

Podolny, J.M., and J.N. Baron. “Resources and Relationships: Social Networks and Mobility in your Workplace." American Sociology Review 62 (1997), 673-693.

Porter, M.E. The Competitive Advantage of the Nations. New York: The Free Press, 1990.

Portes, A., and J. Sensenbrenner. "Embeddedness and Immigration: Notes on the Social Determinants of Economic Action." American Journal of Sociology 98 (1993), 1320-1350.

Pouder, R., and C.H. John. "Hot Spots and Blind Spots: Geographic Clusters of Firms and Innovation." Academy of Management Review 21 (1996), 1192-1225.

Pyke F., and W. Sengenberger. Industrial Districts and Local Economic Regeneration. Geneva: International Institute for Labor Studies, 1992.

Rabellotti, R. "Is There an 'Industrial District Model'? Footwear Districts in Italy and Mexico Compared." World Development 23 (1995), 29-41.

Rowley, T., D. Behrens, and D. Krackhardt. "Redundant Governance Structures: An Analysis of Structural and Relational Embeddedness in the Steel and Semiconductor Industries." Strategic Management Journal 21 (2000), 369-386.

Russo, M. "Technical Change and the Industrial District. The Role of Interfirm Relations in the Growth and Transformation of Ceramic Tile Production in Italy." Research Policy 14 (1985), 329-343.

. "Relazioni tra Imprese e Svolupo Locale." Economia e Politica Industriale 93 (1997), 105-137.

Saxenian, A. "The Origin and Dynamics of Production Networks in Silicon Valley." Research Policy 20 (1991), 423-437.

- Regional Advantage: Culture and Competition in Silicon Valley and Route

128. Cambridge, Mass.: Harvard University Press, 1994.

Schmitz, H. "Small Shoemakers and Fordist Giants: Tales of Superclusters." World Development 23 (1995), 9-28.

Scott, A. “The Aerospace-Electronics Industrial Complex of Southern California: The Formative Years, 1940-1960." Research Policy 20 (1991), 439-456. 
Storper, M. "The Limits to Globalization: Technology Districts and International Trade." Economic Geography 68 (1992), 60-93.

Storper, M., and B. Harrison. "Flexibility, Hierarchy and Regional Development: The Changing Structure of Industrial Production Systems and their Forms of Governance in 1990's." Research Policy 20 (1991), 407-422.

Tomlinson, M. "The Learning Economy and Embodied Knowledge Flows in Great Britain." Journal of Evolutionary Economics 9 (1999), 431-455.

Utili, G., M. Sarti, and F. Gobbo. L'industria delle Piastrelle di Ceramica nel Mondo. I Principali Paese Produttori. Modena: Nomisma-Edi., 1983.

Uzzi, B. "The Sources and Consequences of Embeddedness for the Economic Performance of Organizations." American Sociological Review 61 (1996), 674-698. . "Social Structure and Competition in Interfirm Networks: The Paradox of Embeddedness." Administrative Science Quarterly 42 (1997), 35-67.

Ybarra, J.A. Industrial Districts and the Valencian Community. OIT, Discussion Papers DP/44. Geneva: New Industrial Organisation Programme, 1991. 